Volume 1 Issue 1, January 2022: pp.63-75 Copyright@ NoLaJ.

Master of Notary, Faculty of Law, Lambung Mangkurat University,

Banjarmasin, South Kalimantan, Indonesia. ISSN: 2808-7860 | e-ISSN: 2808-7348

Open Access at: https://notarylaw.journal.ulm.ac.id/index.php/nolaj

\title{
Tukar Menukar Harta Benda Wakaf dalam Pengadaan Tanah bagi Pembangunan untuk Kepantingan Umum
}

\author{
Aditya Putra Patria \\ Angkasa Pura Makassar \\ Jalan Raya Airport No. 1 Makassar, Sulawesi 90552, Indonesia \\ Email: adityappatria@gmail.com
}

Submitted : 14-10-2021 Reviewed:30-10-2021 Accepted:04-11-2021

\begin{abstract}
Research Objectives: To analyze the synchronization of the exchange of Wakaf property which is the object of land acquisition for development in the public interest, according to Law Number 41 of 2004 concerning Waqf, is related to Law Number 2 of 2012 concerning Land Acquisition for Development in the Public Interest and its implementing regulations in which in submitting an exchange for a waqf object, it can only be done after there is evidence of ownership of the temporary exchange property in the process of land acquisition in development for the public interest, not waiting for the availability of replacement land. Based on the research, it is obtained that the form of compensation in the form of money is more beneficial in the case of waqf property which is the object of land acquisition for development in the public interest. Research Results: there is an unsynchronization between Presidential Regulation Number 71 Year 2012 and Government Regulation Number 42 Year 2006 Jo. Government Regulation Number 25 Year 2018 whereby in the filing of the exchange of waqf objects can only be done after there is evidence of ownership of temporary exchange assets in the process of land acquisition in development for public interest, not waiting for the availability of replacement land. Based on the research, it is obtained that the form of compensation in the form of money is more beneficial in the case of waqf property which is the object of land acquisition for development for public interest.
\end{abstract}

Keywords : Land Acquisition Law; Waqf; Waqf Law;

Abstrak:Tujuan Penelitian: Menganalisis sinkronisasi pertukaran Wakaf harta benda yang menjadi objek pengadaan tanah untuk pembangunan untuk kepentingan umum, menurut Undang-Undang Nomor 41 Tahun 2004 tentang Wakaf, terkait dengan Undang-Undang Nomor 2 Tahun 2012 tentang Pengadaan Tanah untuk Pembangunan Untuk Kepentingan Umum dan pelaksanaannya peraturan dimana dalam pengajuan penukaran suatu benda wakaf hanya dapat dilakukan setelah ada bukti kepemilikan barang tukar sementara dalam proses pengadaan tanah dalam pembangunan untuk kepentingan umum, tidak menunggu untuk ketersediaan lahan pengganti. Berdasarkan penelitian, diperoleh bahwa bentuk ganti rugi dalam bentuk uang lebih bermanfaat dalam hal harta benda wakaf yang menjadi objek pengadaan tanah untuk pembangunan untuk kepentingan umum. Hasil Penelitian: terdapat ketidaksinkronan antara Peraturan Presiden Nomor 71 Tahun 2012 dengan Peraturan Pemerintah Nomor 42 Tahun 2006 Jo. Peraturan Pemerintah Nomor 25 Tahun 2018 dimana dalam pengajuan penukaran benda wakaf hanya dapat dilaku- 
kan setelah ada bukti kepemilikan barang tukar sementara dalam proses pengadaan tanah dalam pembangunan untuk kepentingan umum, tidak menunggu tersedianya tanah pengganti. . Berdasarkan penelitian diperoleh bahwa bentuk ganti rugi berupa uang lebih bermanfaat dalam hal harta benda wakaf yang menjadi objek pengadaan tanah untuk pembangunan untuk kepentingan umum.

Kata Kunci: Hukum Wakaf; UU Pengadaan Tanah; Wakaf;

\section{PENDAHULUAN}

Salah satu mekanisme dalam pelaksanaan pengadaan tanah untuk kepentingan umum adalah pelaksanaan ganti kerugian. Pasal 20 Perpres 71/2012 menentukan bahwa pelaksanaan ganti kerugian terhadap tanah wakaf dilakukan sesuai dengan ketentuan peraturan perundang-undangan di bidang wakaf. Dalam praktiknya, ketika peraturan perundang-undangan di bidang wakaf (khususnya terkait tukar menukar harta benda wakaf) diterapkan dalam proses pengadaan tanah untuk kepentingan umum terjadi benturan. Setiap tahapan dalam pengadaan tanah untuk kepentingan umum tentu mengedepankan proses yang cepat dan transparan, namun ketika proses pengadaan tanah untuk kepentingan umum tunduk pada peraturan perundang-undangan di bidang wakaf, proses yang cepat tidak dapat direalisasikan.

Secara proses tukar menukar harta benda wakaf yang dimulai dari nadzir mengajukan permohonan masih jauh lebih cepat dibandingkan proses pengadaan tanah untuk kepentingan umum. Namun kelengkapan dokumen yang harus dipenuhi sebelum nadzir mengajukan permohonan tukar menukar, yaitu dokumen harta benda penukar itulah yang menjadi faktor penyebab lamanya proses tukar menukar harta benda wakaf.

Pasal 77 ayat (5) Perpres 71/2012 menentukan bahwa pemberian ganti kerugian dilaksanakan tanpa menunggu tersedianya tanah pengganti, namun Pasal 51 ayat 2 huruf a PP 42/2006 jo. PP 25/2018 mengatur sebaliknya, bahwa pengajuan proses tukar menukar baru dapat dilaksanakan apabila telah ada bukti kepemilikan harta benda penukar. Tanda bukti kepemilikan tanah adalah berupa sertipikat. Hal ini berarti instansi yang memerlukan harta benda wakaf harus memiliki tanah yang telah bersertipikat atas nama instansi tersebut.

Salah satu contoh kasus yang terjadi adalah proses tukar menukar benda wakaf, yaitu Langgar Darul Hidayah yang berada di area pengembangan Bandar Udara Syamsudin Noor Banjarmasin. Pada tahun 2012, PT Angkasa Pura I (Persero) telah memulai rencana perluasan bandar udara dengan cara melakukan pengadaan tanah terhadap lahan-lahan di sekitar area perluasan. Pada area perluasan lahan untuk pengembangan Bandar Udara Syamsudin Noor - Banjarmasin terdapat Fasilitas Umum dan Fasilitas Sosial milik Pemerintah Kota Banjarbaru yang salah satunya berupa Langgar Darul Hidayah di RT 43, RW 09, Kelurahan Syamsudin Noor. Langgar Darul Hidayah terdaftar sebagai Harta Benda Wakaf di Badan Wakaf Indonesia. Berdasarkan Pasal 40 dan 41 UU 41/2004, Harta Benda wakaf dapat ditukar untuk kepentingan umum sesuai dengan Rencana Umum Tata Ruang (RUTR) berdasarkan ketentuan yang berlaku dan tidak bertentangan dengan syariah setelah memperoleh izin tertulis dari Menteri atas persetujuan Badan Wakaf Indonesia. Dalam pelaksanaannya, proses tukar menukar harta benda wakaf membutuhkan waktu yang sangat lama dan proses yang sangat panjang, terlebih apabila perluasan Bandar Udara Syamsudin Noor termasuk 
ke dalam Proyek Strategis Nasional (PSN) yang diberikan target penyelesaian dalam waktu yang singkat.

Pada November 2015, Panitia Pengadaan Tanah telah menyampaikan hasil ganti kerugian untuk Langgar Darul Hidayah, namun hingga saat penulisan penelitian ini, proses tukar menukar belum selesai dilaksanakan, yaitu sekitar 4 tahun sejak hasil penilaian ganti kerugian disampaikan.

Ketika dilaksanakan secara massal, Undang-Undang No. 2 Tahun 2012 tidak cukup mengatur secara khusus terkait pengesampingan beberapa ketentuan dalam UU Wakaf sehingga dari proses yang sudah berjalan, $1 \mathrm{~cm}^{2}$ harta benda wakafpun lebih rumit penyelesaiannya daripada proses pengadaan tanah secara keseluruhan. Pemerintah mengeluarkan kebijakan dengan menerbitkan Peraturan Presiden Nomor 3 Tahun 2016 Tentang Percepatan Pelaksanaan Proyek Strategis Nasional dan sebagai upaya perbaikan atas proses tukar menukar harta benda wakaf diterbitkan Peraturan Pemerintah Nomor 25 Tahun 2018 Tentang Perubahan Peraturan Pemerintah Nomor 61 Tahun 2006 Tentang Peraturan Pelaksanaan Undang-Undang Nomor 41 Tahun 2004 Tentang Wakaf, namun demikian prosesnya tetap berlarut-larut dan memakan waktu yang lama dan seringkali sampai Panitia Pengadaan Tanah habis masa tugasnya. Hal tersebut mengakibatkan terjadi saling lempar tanggung jawab antara Panitia Pengadaan Tanah dengan instansi yang membutuhkan tanah dan tentunya hal tersebut bukan solusi atas permasalahan yang sedang dihadapi. Berdasar latar belakang diatas, yang menjadi rumusan masalah penelitian ini adalah: pertama Apakah proses tukar menukar harta benda wakaf sebagaimana diamanatkan dalam peraturan perundang-undangan tentang wakaf telah sinkron dengan proses pengadaan tanah untuk kepentingan umum? Kedua Apakah bentuk ganti kerugian yang tepat dalam hal terdapat harta benda wakaf yang menjadi objek pengadaan tanah dalam proses Pengadaan Tanah Bagi Pembangunan Untuk Kepentingan Umum?

\section{METODE PENELITIAN}

Penelitian tentang "Tukar Menukar Harta Benda Wakaf dalam Pengadaan Tanah Bagi Kepentingan Umum" merupakan suatu penelitian hukum normatif. Dalam penelitian ini, Peneliti melakukan analisis terhadap peraturan perundang-undangan yang berkaitan dengan tukar menukar harta benda wakaf dan pengadaan tanah untuk kepentingan umum.

Penelitian ini bersifat preskriptif analisis. Penelitian ini dimaksudkan untuk memberikan argumentasi atas hasil penelitian sehingga menghasilkan pengaturan yang sistematis terkait tukar menukar harta benda wakaf dalam pengadaan tanah untuk kepentingan umum. Dalam penelitian ini, Peneliti menggunakan beberapa pendekatan, diantaranya:

1. Pendekatan peraturan perundangan (statute approach);

2. Pendekatan konseptual (conceptual approach).

\section{III.ANALISIS DAN PEMBAHASAN}

1.1 Proses Tukar-Menukar Harta Benda Wakaf dalam Peraturan Perundang-Undangan tentang Wakaf Dikaitkan dengan Proses Pengadaan Tanah untuk Kepentin- 


\section{gan Umum}

\section{A. Proses Tukar Menukar Harta Benda Wakaf}

Dalam Pasal 1451 KUH Perdata disebutkan bahwa tukar menukar adalah suatu persetujuan dengan mana kedua belah pihak mengikatkan diri untuk saling memberikan suatu barang secara timbal balik sebagai ganti suatu barang lain. ${ }^{1} \mathrm{Se}-$ lanjutnya pengertian harta benda wakaf berdasarkan Pasal 1 angka 5 UU 41/2004 yaitu harta benda yang memiliki daya tahan lama dan/atau manfaat jangka panjang serta mempunyai nilai ekonomi menurut syariah yang diwakafkan oleh Wakif. Pasal 40 UU 41/2004 menyebutkan bahwa harta benda wakaf yang sudah diwakafkan dilarang untuk:

1. Dijadikan jaminan

2. Disita

3. Dihibahkan

4. Dijual

5. Diwariskan

6. Ditukar

7. Dialihkan dalam bentuk pengalihan hak lainnya.

Terdapat pengecualian dalam larangan sebagaimana ketentuan diatas, yaitu harta benda wakaf dapat dilakukan tukar-menukar apabila digunakan untuk kepentingan umum sesuai dengan rencana umum tata ruang (RUTR) berdasarkan ketentuan peraturan perundang-undangan yang berlaku dan tidak bertentangan dengan syariah. Pelaksanaan tukar menukar tersebut hanya dapat dilakukan setelah memperoleh izin tertulis dari Menteri atas persetujuan Badan Wakaf Indonesia. Harta benda wakaf yang sudah diubah statusnya wajib ditukar dengan harta benda yang manfaat dan nilai tukar sekurang-kurangnya sama dengan harta benda wakaf semula.

Dalam hal penukaran harta benda Wakaf digunakan untuk kepentingan umum dan memiliki luas sampai dengan $5.000 \mathrm{~m}^{2}$ (lima ribu meter persegi), Menteri memberi mandat kepada Kepala Kantor Wilayah untuk menerbitkan izin tertulis. Menteri menerbitkan izin tertulis penukaran harta benda Wakaf berdasarkan:

a. harta benda penukar memiliki sertifikat atau bukti kepemilikan sah sesuai dengan ketentuan peraturan perundang-undangan; dan

b. nilai dan manfaat harta benda penukar paling kurang sama dengan harta benda Wakaf semula yang ditetapkan oleh Kepala Kantor berdasarkan rekomendasi Tim Penetapan.

Mekanisme izin tertulis dari Menteri dapat dijelaskan sebagai berikut:

a. Nazhir mengajukan permohonan secara tertulis kepada Menteri melalui Kepala Kantor dengan melampirkan:

1) dokumen harta benda Wakaf meliputi Akta Ikrar Wakaf, akta pengganti

1 Tim Gramedia Pressindo, Kitab Undang-Undang Hukum KUH Per, KUHP, KUHAP Beserta Penjelasannya. (Jakarta: Gramedia Pressindo, 2015). 
Akta Ikrar Wakaf, sertifikat Wakaf, sertifikat harta benda, atau bukti lain kepemilikan harta benda yang sah sesuai dengan ketentuan peraturan perundang-undangan.

2) dokumen harta benda penukar berupa sertifikat atau bukti lain kepemilikan harta benda yang sah sesuai dengan ketentuan peraturan perundangundangan.

3) hasil penilaian harta benda Wakaf yang akan ditukar, dan penukamya oleh Penilai atau Penilai Publik; dan

4) kartu tanda penduduk Nazhir.

b. Kepala Kantor membentuk Tim Penetapan paling lama 5 (lima) hari kerja sejak menerima permohonan dari Nazhir.

c. Tim Penetapan mengajukan rekomendasi tukar-menukar harta benda wakaf paling lama 5 (lima) hari kerja sejak Penilai atau Penilai Publik menyerahkan hasil penilaian kepada Kepala Kantor dan tembusannya kepada Tim Penetapan.

d. Kepala Kantor menetapkan dan mengirimkan hasil penilaian tukar-menukar harta benda Wakaf kepada Menteri dan kepada BWI paling lama 4 (empat) hari kerja.

e. BWI memberikan persetujuan kepada Menteri paling lama 5 (lima) hari kerja sejak menerima hasil penilaian tukar-menukar harta benda Wakaf dari Kepala Kantor; dan

f. Menteri menerbitkan izin tertulis tukar-menukar harta benda wakaf paling lama 15 (lima belas) hari kerja sejak menerima persetujuan dari BWI.

Kepala Kantor Wilayah menerbitkan izin tertulis berdasarkan:

a. persetujuan dari BWI provinsi;

b. harta benda penukar memiliki sertifikat atau bukti kepemilikan sah sesuai dengan ketentuan peraturan perundang-undangan; dan

c. nilai dan manfaat harta benda penukar paling sedikit sama dengan harta benda Wakaf semula yang ditetapkan oleh Kepala Kantor berdasarkan rekomendasi Tim Penetapan.

lzin tertulis dari Kepala Kantor Wilayah diperoleh dengan mekanisme:

a. Nazhir mengajukan permohonan secara tertulis kepada Kepala Kantor Wilayah melalui Kepala Kantor dengan melampirkan:

1) dokumen harta benda Wakaf meliputi Akta Ikrar Wakaf atau akta pengganti Akta Ikrar Wakaf dan sertifikat Wakaf atau sertifikat harta benda serta bukti lain kepemilikan harta benda yang sah sesuai dengan ketentuan peraturan perundang-undangan;

2) dokumen harta benda penukar berupa sertifikat atau bukti lain kepemilikan harta benda yang sah sesuai dengan ketentuan peraturan perundang-undangan;

3) hasil penilaian harta benda Wakaf yang akan ditukar dan penukamya oleh Penilai atau Penilai Publik; dan 
4) kartu tanda penduduk Nazhir.

b. Kepala Kantor Wilayah membentuk Tim Penetapan paling lama 5 (lima) hari kerja sejak menerima permohonan dari Nazhir.

c. Tim Penetapan mengajukan rekomendasi tukarmenukar harta benda Wakaf paling lama 5 (lima) hari kerja sejak Penilai atau Penilai Publik menyerahkan hasil penilaian kepada Kepala Kantor dan tembusannya kepada Tim Penetapan;

d. Kepala Kantor menetapkan dan mengirimkan hasil penilaian tukar-menukar harta benda Wakaf kepada Kepala Kantor Wilayah dan kepada BWI provinsi paling lama 4 (empat) hari kerja;

e. BWI provinsi memberikan persetujuan kepada Kepala Kantor Wilayah paling lama 5 (lima) hari kerja sejak menerima hasil penilaian tukar-menukar harta benda wakaf dari Kepala Kantor; dan

f. Kepala Kantor Wilayah atas nama Menteri menerbitkan izin tertulis tukar-menukar harta benda Wakaf paling lama 10 (sepuluh) hari kerja sejak menerima persetujuan dari BWI provinsi.

Instansi atau pihak yang akan menggunakan tanah Wakaf wajib mengajukan permohonan sertifikat Wakaf atas nama Nazhir terhadap tanah pengganti kepada kantor pertanahan setempat paling lama 10 (sepuluh) hari kerja sejak memperoleh izin tertulis dari Menteri atau Kepala Kantor Wilayah. Setelah menerima permohonan sertifikat wakaf, Kantor pertanahan setempat menerbitkan sertilikat Wakaf sesuai dengan ketentuan peraturan perundangundangan.

\section{A. Prosedur Pengadaan Tanah Bagi Pembangunan Untuk Kepentingan Umum}

Pengadaan tanah untuk kepentingan umum secara garis besar, terdiri dari empat tahapan, yaitu perencanaan, persiapan, pelaksanaan dan penyerahan hasil. Masing-masing tahapan tersebut dijelaskan sebagaimana uraian dibawah ini.

a. Perencanaan

Perencanaan pengadaan tanah diantaranya diatur dalam ketentuan Pasal 1415 UU 2/2012 dan Pasal 3-7 Perpres 7/2012 beserta perubahannya.

b. Persiapan

Persiapan pengadaan tanah diantaranya diatur dalam ketentuan Pasal 1626 UU 2/2012 dan Pasal 8-48 Perpres 71/2012 beserta perubahannya.

c. Pelaksanaan

Pelaksanaan pengadaan tanah diantaranya diatur dalam ketentuan sebagai berikut: Pasal 27-47 UU 2/2012; Pasal 49-111 Perpres 71/2012 beserta perubahannya dan Pasal 5-45 Perkaban 5/2012. Pelaksanaan Pengadaan Tanah dilaksanakan oleh Kepala Kantor Wilayah BPN selaku Ketua Pelaksana Pengadaan Tanah. Tahapan pelaksanaan pengadaan tanah untuk kepentingan umum secara umum terdiri dari sembilan tahapan, yaitu penyiapan pelaksanaan, inventarisasi dan identifikasi, penetapan penilai, musyawarah penetapan ganti kerugian, pemberian ganti kerugian, penitipan ganti keru- 
gian, pelepasan obyek pengadaan tanah, pemutusan hubungan hukum antara Pihak yang Berhak dengan obyek pengadaan tanah dan pendokumentasian peta bidang, daftar nominatif dan data administrasi pengadaan tanah.

d. Penyerahan hasil

Penyerahan hasil pengadaan tanah diantaranya diatur dalam ketentuan sebagai berikut: Pasal 48-50 UU 2/2012; Pasal 112-114 Perpres 71/2012 beserta perubahannya dan Pasal 46-48 Perkaban 5/2012.

Berdasarkan uraian tahapan proses pengadaan tanah untuk kepentingan umum diatas, ketentuan Pasal 20 Perpres 71/2012 yang menentukan bahwa pelaksanaan ganti kerugian terhadap tanah wakaf dilakukan sesuai dengan ketentuan peraturan perundang-undangan di bidang wakaf menjadi faktor utama yang menyebabkan proses pengadaan tanah terutama tanah wakaf menjadi terhambat dan berlarutlarut. Seyogyanya pelaksa-naan ganti kerugian terhadap tanah wakaf tetap tunduk pada UU 2/2012 beserta peraturan pelaksanaanya.

B. Sinkronisasi Proses Tukar Menukar Harta Benda Wakaf dalam Peraturan Perundang-undangan tentang Wakaf dengan Proses Pengadaan Tanah Untuk Kepentingan Umum

Pasal 77 ayat (3) dan (4) Perpres 71/2012 beserta perubahannya berisi ketentuan bahwa pemberian ganti kerugian dilakukan bersamaan dengan pelepasan hak oleh pihak yang berhak tanpa menunggu tersedianya tanah pengganti tidak sinkron dengan pengaturan sebagaimana dalam Pasal 51 ayat 2 huruf a PP 42/2006 jo. PP 25/2018 yang mengatur bahwa pengajuan proses tukar menukar baru dapat dilaksanakan apabila telah ada bukti kepemilikan harta benda penukar. Untuk mencapai pembangunan yang sesuai dengan tenggat waktu yang ditetapkan, maka seyogyanya proses tukar menukar harta benda wakaf sejalan dengan ketentuan Pasal 77 ayat (3) dan (4) Perpres 71/2012 beserta perubahannya berisi ketentuan bahwa pemberian ganti kerugian dilakukan bersamaan dengan pelepasan hak oleh pihak yang berhak tanpa menunggu tersedianya tanah pengganti.

1.2 Bentuk Ganti Kerugian yang Tepat terhadap Harta Benda Wakaf yang menjadi Obyek Pengadaan Tanah dalam Proses Pengadaan Tanah bagi Pembangunan untuk Kepentingan Umum

A. Kendala yang Dihadapi dalam Proses Tukar Menukar Harta Benda Wakaf dalam Pengadaan Tanah untuk Kepentingan Umum

Kendala utama yang dihadapi adalah terkait dengan pengaturan pada Pasal 51 ayat 2 huruf a PP 42/2006 jo. PP 25/2018 yang mengamanatkan bahwa pengajuan proses tukar menukar baru dapat dilaksanakan apabila telah ada bukti kepemilikan harta benda penukar. Pengaturan tersebut berbeda dengan pada proses pengadaan tanah pada umumnya, yaitu pemberian ganti kerugian dilakukan bersamaan dengan pelepasan hak oleh pihak yang berhak tanpa menunggu tersedianya tanah pengganti sebagaimana diatur dalam Pasal 77 ayat (3) dan (4) Perpres 
$71 / 2012$ beserta perubahannya. Hal ini berarti instansi yang memerlukan harta benda wakaf harus memiliki tanah yang telah bersertipikat atas nama instansi tersebut.

Pemilikan hak atas tanah oleh seseorang oleh seseorang atau badan hukum harus di buktikan. Pembuktian kepemilikan hak atas tanah di lakukan atau ditunjukan dengan berbagai macam alat bukti. Berdasarkan Pasal 19 ayat (2) huruf c UU 5/1960 dinyatakan bahwa akhir kegiatan pendaftaran tanah yang diadakan oleh Pemerintah adalah pemberian surat tanda bukti hak yang berlaku sebagai alat pembuktian yang kuat. ${ }^{2}$ UU 5/1960 tidak menyebut nama surat tanda bukti hak atas tanah yang didaftar. Penyebutan surat tanda bukti hak atas tanah terdapat dalam PP 24 Tahun 1997 dengan istilah sertipikat. Pengertian sertipikat berdasarkan Pasal 1 angka 20 PP 24 Tahun 1997 adalah surat tanda bukti hak sebagaimana dimaksud dalam pasal 19 ayat (2) huruf c UUPA untuk hak atas tanah, hak pengelolaan, tanah wakaf, hak milik atas satuan rumah susun dan hak tanggungan yang masing-masing sudah dibukukan dalam buku tanah yang bersangkutan.

Proses untuk mendapatkan tanah pengganti hingga dilakukan balik nama atas nama instansi yang memerlukan tanah tidaklah sebentar. Secara garis besar ada tiga tahapan yang harus dilakukan agar tanah pengganti harta benda wakaf bersertipikat atas nama instansi yang memerlukan tanah:

a. Instansi yang memerlukan tanah mencari tanah pengganti yang memiliki manfaat dan nilai tukar yang sekurang-kurangnya sama dengan tanah wakaf yang akan ditukar.

b. Instansi yang memerlukan tanah melakukan transaksi dengan pihak yang memiliki tanah yang manfaat dan nilai tukar yang sekurang-kurangnya sama dengan tanah wakaf yang akan ditukar.

c. Pengajuan balik nama sertipikat/permohonan hak atas tanah

Dalam praktiknya, proses untuk menyediakan tanah pengganti atas nama instansi yang memerlukan tanah itulah yang menjadi kendala utama pengadaan tanah untuk kepentingan umum terhadap obyek tanah wakaf menjadi berlarutlarut. Salah satu contoh kasus yang terjadi adalah proses tukar menukar benda wakaf, yaitu Langgar Darul Hidayah yang berada di area pengembangan Bandar Udara Syamsudin Noor Banjarmasin yang dikelola oleh PT Angkasa Pura I (Persero). Pada tahun 2012, PT Angkasa Pura I (Persero) telah memulai rencana perluasan bandar udara dengan cara melakukan pengadaan tanah terhadap lahanlahan di sekitar area perluasan.

Pada area perluasan lahan untuk pengembangan Bandar Udara Syamsudin Noor - Banjarmasin terdapat Fasilitas Umum dan Fasilitas Sosial milik Pemerintah Kota Banjarbaru yang salah satunya berupa Langgar Darul Hidayah di RT 43, RW 09, Kelurahan Syamsudin Noor. Langgar Darul Hidayah terdaftar sebagai Harta Benda Wakaf di Badan Wakaf Indonesia berdasarkan Sertipikat Hak Milik

\footnotetext{
${ }^{2}$ Urip Santoso, Hukum Agraria Kajian Komprehensif(Jakarta: Kencana, 2012).
} 
Nomor 2969 dengan perubahan menjadi tanah wakaf sesuai Surat Pengesahan Nadzir tanggal 12 Juli 1988 Nomor W.5/001/K2-I2/II/1990 seluas 282 m². $^{2}$

B. Bentuk Ganti Kerugian Yang Tepat Terhadap Harta Benda Wakaf yang Menjadi Obyek Pengadaan Tanah dalam Proses Pengadaan Tanah Bagi Pembangunan Untuk Kepentingan Umum

Perubahan dan atau pengalihan harta benda wakaf pada prinsipnya bisa dilakukan selama memenuhi syarat tertentu dan dengan mengajukan alasan-alasan sebagai-mana yang telah ditentukan oleh undang-undang yang berlaku. Perubahan terhadap harta benda yang diwakafkan dapat dilakukan menurut Hukum Islam dengan jalan isthisan, yaitu suatu cara menentukan hukum dengan jalan menyimpang dari ketentuan yang sudah ada demi keadilan dan kepentingan sosial yang menghendaki. ${ }^{3}$

Sebagaimana telah diuraikan dalam sub bab sebelumnya, proses tukar-menukar harta benda wakaf yang terjadi saat ini harus menempuh jalan yang panjang dan waktu yang lama, terlebih dengan adanya syarat bahwa pengajuan proses tukar menukar baru dapat dilaksanakan apabila telah ada bukti kepemilikan harta benda penukar. Hal tersebut dinilai sangat tidak efektif sehingga menghambat upaya pengadaan tanah untuk kepentingan umum yang dituntut untuk segera selesai. Oleh karena itu diperlukan diperlukan suatu perubahan pengaturan agar proses tukar menukar harta benda wakaf dalam pengadaan tanah untuk kepentingan umum dapat berjalan dengan efektif dan efisien.

Membahas konsep hukum untuk masa depan maka erat kaitannya dengan teori hukum progresif yang dikembangkan oleh Satjipto Rahardjo. Hukum progresif berpegang pada paradigma "hukum untuk manusia". ${ }^{4}$ Hukum progresif bisa diibaratkan seperti papan petunjuk yang memperingatkan bahwa hukum harus selalu merobohkan, mengganti, dan membebaskan hukum yang mandek karena tidak mampu melayani lingkungan yang berubah. Hukum progresif tidak melihat hukum sebagai suatu produk final, melainkan yang secara terus menerus masih harus dibangun. ${ }^{5}$ Dalam perspektif hukum progresif tidak seharusnya terjebak pada formalitas hukum yang pada praktiknya menunjukkan banyak kontradiksi dan kebuntuan dalam pencarian kebenaran dan keadilan substansial.

Perlu dipahami bahwa undang-undang pada hakikatnya tidak selalu jelas. ${ }^{6} \mathrm{Hal}$ ini karena terkadang pada undang-undang tidak secara langsung menyediakan pasal-pasal yang bisa memecahkan suatu persoalan. Maka sebuah kekeliruan jika memandang undang-undang bisa mengatur segalanya secara tuntas.

Sebagaimana telah diuraikan dalam sub bab sebelumnya, diterbitkannya PP 25/2018 dikarenakan ketentuan dalam PP 42/2006 tidak sejalan dengan perun-

\footnotetext{
${ }^{3}$ Elsi Kartika Sari, Pengantar Hukum Zakat Dan Wakaf (Jakarta: PT Grasindo, 2006).

${ }^{4}$ Satjipto Rahardjo, Hukum Progresif Sebuah Sinestesa Hukum Indonesia (Yogyakarta: Genta Publishing, 2009).

${ }^{5}$ Rahardjo.

${ }^{6}$ Rahardjo.
} 
dang-undangan yang mengatur tentang pengadaan tanah bagi pembangunan untuk kepentingan umum, khususnya terkait dengan proses tukar menukar harta benda wakaf untuk kepentingan umum. PP 25/2018 telah mengatur pembatasan jangka waktu masing-masing proses tukar menukar harta benda wakaf mulai dari pengajuan permohonan tertulis sampai dengan terbitnya izin atas permohonan tersebut yang sebelumnya tidak diatur dalam PP 42/2006. Namun pada kenyataannya pembatasan jangka waktu tersebut tidak memiliki dampak besar terhadap proses tukar menukar harta benda wakaf agar menjadi lebih cepat dan efisien.

Kendala utama yang dihadapi adalah terkait dengan pengaturan pada Pasal 51 ayat 2 huruf a PP 42/2006 jo. PP 25/2018 yang mengamanatkan bahwa pengajuan proses tukar menukar baru dapat dilaksanakan apabila telah ada bukti kepemilikan harta benda penukar dan Pasal 41 ayat (3) UU 41/2004 mempersyaratkan bahwa harta benda wakaf yang sudah diubah statusnya karena pengadaan tanah untuk kepentingan umum wajib ditukar dengan harta benda yang manfaat dan nilai tukar sekurang-kurangnya sama dengan harta benda wakaf semula. Hal ini berarti instansi yang memerlukan harta benda wakaf harus memiliki tanah yang telah bersertipikat atas nama instansi tersebut.

Dalam pelaksanaannya proses untuk mencari harta benda penukar yang memiliki manfaat dan nilai tukar sekurang-kurangnya sama dengan harta benda wakaf semula dan telah bersertipikat atas nama instansi yang memerlukan tanah membutuhkan waktu bertahun-tahun. Hal tersebut tidak sejalan dengan tujuan pengadaan tanah untuk kepentingan umum yang dituntut untuk segera melaksanakan pembangunan. Oleh karenanya, bentuk ganti kerugian yang mensyaratkan memiliki manfaat dan nilai tukar sekurang-kurangnya sama dengan harta benda wakaf semula dan telah bersertipikat atas nama instansi yang memerlukan tanah merupakan kendala terbesar dalam proses tukar menukar harta benda wakaf.

Bentuk ganti kerugian yang tepat sebagai harta benda wakaf penukar adalah berupa uang. Hal ini dikarenakan uang merupakan alat pembayaran yang paling praktis dan cepat dibandingkan dengan menyediakan tanah dan/atau bangunan pengganti. Ganti kerugian berupa uang dalam pengadaan tanah untuk kepentingan umum sejalan dengan Pasal 75 Perpres 71/2012 beserta perubahannya yang mengamanatkan bahwa Pelaksana Pengadaan Tanah mengutamakan pemberian dalam bentuk uang. Pemberian Ganti Kerugian dalam bentuk uang diberikan dalam mata uang rupiah dan dilakukan melalui jasa Perbankan atau pemberian secara tunai yang disepakati antara pihak yang berhak dengan instansi yang memerlukan tanah.

Uang dapat diartikan sebagai segala sesuatu yang diterima oleh umum (khalayak ramai) sebagai alat penukar yang dinyatakan dalam kesatuan hitung dan yang dapat dianggap sebagai alat pembayaran yang sah. ${ }^{7}$ Teori lain menyatakan uang sebagai sesuatu benda yang secara umum diterima sebagai alat pembayaran

${ }^{7}$ R.A. Rahman Prawiraamidjaya, Ekonomi Moneter (Bandung: Alumni, 1970). 
untuk pembelian barang-barang dan jasa serta pembayaran hutang. Dipandang juga sebagai kekayaan yang dimiliki seseorang yang dapat digunakan untuk membayar sejumlah utang dengan kepastian dan tanpa penundaan. ${ }^{8}$

Definisi lain menyatakan bahwa uang adalah "suatu benda yang dapat diterima secara umum sebagai alat tukar menukar dan pada waktu yang sama bertindak juga sebagai penimbun kekayaan". 9 Sir Dennis Robertson dalam bukunya "Money", sebagai-mana dikutip oleh Syamsuddin Munir, mendefinisikan uang sebagai "sesuatu yang diterima secara luas sebagai pembayaran atas barang-barang atau dipergunakan di dalam bermacam-macam kewajiban perdagangan lainlain". ${ }^{10}$ Dalam Kamus Besar Bahasa Indonesia, uang dinyatakan sebagai "alat tukar atau standar pengukur nilai (kesatuan hitungan) yang sah, yang dikeluarkan oleh pemerintah suatu negara berupa kertas, emas, perak, atau lagam lain yang dicetak dengan bentuk dan gambar tertentu". ${ }^{11}$

Wakaf sendiri tidak termasuk perintah yang sifatnya "ta'abbudiy" yang tidak bisa dinalar maksudnya, tapi lebih bersifat "ta'aqquliy", yang dapat dinalar maknanya, dan tujuan akhirnya adalah memberi kemaslahatan kepada umat. ${ }^{12}$ Sehingga meskipun harta benda penukar tidak berbentuk sama dengan harta benda wakaf semula, asalkan tujuan akhirnya dapat memberikan kemaslahatan seperti harta benda wakaf semula, maka hal tersebut dapat diperkenankan dan tidak bertentangan dengan syariat. Cara termudah yang dapat dilakukan adalah instansi yang memerlukan tanah mengganti harta benda wakaf yang akan ditukar dalam bentuk uang, yang selanjutnya Nadzir berwenang menggunakan uang tersebut untuk pembelian lahan dan pendirian bangunan pengganti.

Bentuk ganti kerugian yang tepat dalam hal terdapat harta benda wakaf yang menjadi objek pengadaan tanah dalam proses pengadaan tanah bagi pembangunan untuk kepentingan umum adalah berupa uang. Ganti kerugian berupa uang dalam pengadaan tanah untuk kepentingan umum sejalan dengan Pasal 75 Perpres 71/2012 beserta perubahannya yang mengamanatkan bahwa Pelaksana Pengadaan Tanah mengutamakan pemberian dalam bentuk uang.

\section{PENUTUP}

\section{Kesimpulan}

1. Proses tukar menukar harta benda wakaf sebagaimana dalam Pasal 51 ayat 2 huruf a Peraturan Pemerintah Nomor 42 Tahun 2006 tentang Pelaksanaan Undang-Undang Nomor 41 Tahun 2004 tentang Wakaf yang telah diubah dengan Peraturan Pemerintah Nomor

\footnotetext{
${ }^{8}$ Iswardono, Uang Dan Bank (Yogyakarta: BPFE Universitas Gajah Mada, 1994).

${ }^{9}$ Setiadi Kusuma, Azas-Azas Ekonomi Moneter (Bandung: Alumni, 1969).

${ }^{10}$ Syamsuddin Munir, Dasar-Dasar Ekonomi Tentang Uang Dan Perbankan (Padang: Angkasa Raya, 1995).

${ }^{11}$ Departemen Pendidikan Nasional, Kamus Besar Bahasa Indonesia, Edisi III (Jakarta: Balai Pustaka, 2001).

12 Jamal, Daur Nizhom Al-Waqf Al-Islamy Fi at-Tanmiyah Al-Iqtishadiyah Al-Muashirah (Kairo: Dar as-Salam, 2007).
} 
25 Tahun 2018 tentang Perubahan Atas Peraturan Pemerintah Nomor 42 Tahun 2006 tentang Pelaksanaan Undang-Undang Nomor 41 Tahun 2004 tentang Wakaf yang mengatur bahwa pengajuan proses tukar menukar baru dapat dilaksanakan apabila telah ada bukti kepemilikan harta benda penukar tidak sinkron dengan proses pengadaan tanah untuk kepentingan umum sebagaimana pada Pasal 77 ayat (3) dan (4) Peraturan Presiden Nomor 71 Tahun 2012 tentang tentang Penyelenggaraan Pengadaan Tanah Bagi Pembangunan Untuk Kepentingan Umum sebagaimana telah diubah terakhir dengan Peraturan Presiden Nomor 148 Tahun 2015 tentang Perubahan Keempat Atas Peraturan Presiden Nomor 71 Tahun 2012 tentang Penyelenggaraan Pengadaan Tanah Bagi Pembangunan Untuk Kepentingan Umum yang berisi ketentuan bahwa pemberian ganti kerugian dilakukan bersamaan dengan pelepasan hak oleh pihak yang berhak tanpa menunggu tersedianya tanah pengganti.

2. Bentuk ganti kerugian yang tepat dalam hal terdapat harta benda wakaf yang menjadi objek pengadaan tanah dalam proses pengadaan tanah bagi pembangunan untuk kepentingan umum adalah berupa uang. Instansi yang memerlukan tanah mengganti harta benda wakaf yang akan ditukar dalam bentuk uang, yang selanjutnya Nadzir berwenang menggunakan uang tersebut untuk pembelian lahan dan pendirian bangunan pengganti. Ganti kerugian berupa uang dalam pengadaan tanah untuk kepentingan umum sejalan dengan Pasal 75 Perpres 71/2012 beserta perubahannya yang mengamanatkan bahwa Pelaksana Pengadaan Tanah mengutamakan pemberian dalam bentuk uang.

\section{Saran}

1. Agar pembuat peraturan perundang-undangan menghapus ketentuan Pasal 51 ayat 2 huruf a Peraturan Pemerintah Nomor 42 Tahun 2006 tentang Pelaksanaan Undang-Undang Nomor 41 Tahun 2004 tentang Wakaf yang telah diubah dengan Peraturan Pemerintah Nomor 25 Tahun 2018 tentang Perubahan Atas Peraturan Pemerintah Nomor 42 Tahun 2006 tentang Pelaksanaan Undang-Undang Nomor 41 Tahun 2004 tentang Wakaf yang mengatur bahwa pengajuan proses tukar menukar baru dapat dilaksanakan apabila telah ada bukti kepemilikan harta benda penukar.

2. Agar pembuat peraturan perundang-undangan menghapus ketentuan Pasal 41 ayat (3) UU Nomor 41 Tahun 2004 tentang Wakaf mempersyaratkan bahwa harta benda wakaf yang sudah diubah statusnya karena pengadaan tanah untuk kepentingan umum wajib ditukar dengan harta benda yang manfaat dan nilai tukar sekurang-kurangnya sama dengan harta benda wakaf semula kemudian menggantinya dengan harta benda penukar dalam bentuk uang.

\section{REFERENSI}

Departemen Pendidikan Nasional. Kamus Besar Bahasa Indonesia. Edisi III. Jakarta: Balai Pustaka, 2001.

Iswardono. Uang Dan Bank. Yogyakarta: BPFE Universitas Gajah Mada, 1994.

Jamal. Daur Nizhom Al-Waqf Al-Islamy Fi at-Tanmiyah Al-Iqtishadiyah Al-Muashirah. Kairo:

Dar as-Salam, 2007. 
Kusuma, Setiadi. Azas-Azas Ekonomi Moneter. Bandung: Alumni, 1969.

Munir, Syamsuddin. Dasar-Dasar Ekonomi Tentang Uang Dan Perbankan. Padang: Angkasa Raya, 1995.

Prawiraamidjaya, R.A. Rahman. Ekonomi Moneter. Bandung: Alumni, 1970.

Rahardjo, Satjipto. Hukum Progresif Sebuah Sinestesa Hukum Indonesia. Yogyakarta: Genta Publishing, 2009.

Santoso, Urip. Hukum Agraria Kajian Komprehensif. Jakarta: Kencana, 2012.

Sari, Elsi Kartika. Pengantar Hukum Zakat Dan Wakaf. Jakarta: PT Grasindo, 2006.

Tim Gramedia Pressindo. Kitab Undang-Undang Hukum KUH Per, KUHP, KUHAP Beserta Penjelasannya. Jakarta: Gramedia Pressindo, 2015.

\section{Peraturan Perundang-undangan}

Peraturan Presiden Nomor 71 Tahun 2012Penyelenggaraan Pengadaan Tanah bagi Pembangunan untuk Kepentingan Umum

Peraturan Presiden Nomor 3 Tahun 2016 tentang Percepatan Pelaksanaan Proyek Strategis Nasional (Lembaran Negara Republik Indonesia Tahun 2016 Nomor 4).

Peraturan Pemerintah Nomor 42 Tahun 2006 tentang Pelaksanaan Undang-Undnag Nomor 41 Tahun 2004 tentang Wakaf (Lembaran Negara Republik Indonesia Tahun 2006 Nomor 105, Tambahan Lembaran Negara Nomor 4668) sebagaimana telah diubah dengan Peraturan Pemerintah Nomor 25 Tahun 2018 tentang Perubahan Atas Peraturan Pemerintah Nomor 42 Tahun 2006 tentang Pelaksanaan Undang-Undang

Peraturan Pemerintah Nomor 24 Tahun 1997 tentang Pendaftaran Tanah

Nomor 41 Tahun 2004 tentang Wakaf (Lembaran Negara Republik Indonesia Tahun 2018 Nomor 93, Lembaran Negara Nomor 6217).

Undang-undang Nomor 41 Tahun 2004 tentang Wakaf (Lembaran Negara Republik Indonesia Tahun 2004 Nomor 159, Tambahan Lembaran Negara Nomor 4459).

Undang-undang Nomor 2 Tahun 2012 tentang Pengadaan Tanah Bagi Pembangunan Bagi Kepentingan Umum (Lembaran Negara Republik Indonesia Tahun 2012 Nomor 22, Tambahan Lembaran Negara Nomor 5280).

Undang-Undang Nomor 5 Tahun 1960 Tentang Peraturan Dasar Pokok-Pokok Agraria (Lembaran Negara Republik Indonesia Tahun 1960 Nomor 104, Tambahan Lembaran Negara Nomor 2043). 